\title{
Microbiological and Immunological Studies on Brucellosis in a Hospital in Al-Madinah Al-Munawarah
}

\author{
Manal M.E. Ahmed ${ }^{1 *}$, Ibrahim A. ${ }^{2}$, Abd El-Rahman M. M. ${ }^{2}$ \\ ${ }^{1}$ Ph.D., Pharmacology Department, National Research Centre, Dokki, Giza, Egypt. \\ ${ }^{2}$ Prince Sultan Armed Forces Hospital, Al-Madinah Al-Munawarah,Saudi Arabia
}

\begin{tabular}{l} 
Article Info \\
\hline Article history: \\
Received:22 August 2020 \\
Revised: 18 October 2020 \\
Accepted: 22 October 2020 \\
\hline Keywords: \\
Brucellosis, \\
B. abortus, \\
B. melitensis, \\
Zoonotic Disease, \\
Immunoglobulins \\
Paper Type : \\
Research Article \\
\hline Corresponding Author: \\
Manal M.E. Ahmed \\
Email: \\
Thinktankteam2014@gmail.com
\end{tabular}

\begin{abstract}
Purpose: The study was conducted to estimate the prevalence of brucellosis in Prince Sultan Armed Forces Hospital at Al-Madinah AlMunawarah, Saudi Arabia. The aim was also to determine the most prevalent species of Brucella and to make a comparison between culture and serological methods in diagnosis and to evaluate the levels of sIL-2R and/or IFN- $\gamma$ production to be used as markers of treatment efficacy.

Study Design: Cross-sectional Study

Subjects and Methods: This study was conducted on 65 patients with male: female ratio (2:1) suspected of having brucellosis. It was carried out using slide agglutination test for detection of anti-Brucella antibodies. Also, we estimated anti-Brucella IgG and IgM antibody levels in the sera of examined patients using ELISA. Quantization of human IFN- $\mathrm{\gamma}$ was performed.

Results: The total incidence of brucellosis was 92.3\%. The incidence among males (95.2\%) was higher than that of female (87\%). Brucellosis was detected in all age groups. Most of brucellosis patients were recovered during the period from January to June. Consumption of milk products, heating raw milk and milking animals were the highest risks with an incidence of $100 \%$ followed by drinking raw milk with an incidence of $95 \%$ while cutting raw meat and animal contact were the less risk with an incidence of $80 \%$ and $67 \%$, respectively. The most prevalent species among examined patients was B. melitensis (86\%) and B. abortus (6\%). Brucellosis patients had $63 \%$ and $83 \%$ of anti BrucellaIg $G$ and IgM, respectively. The highest (\%) of patients having positive $\operatorname{IgG}$ and $\operatorname{IgM}$ levels in their sera were among 1/160 standard tube agglutination test (SAT) antibody titer group brucellosis patients were having positive levels of IFN-y. All of them belonged to 1/80 antibody titer group. The mean IFN$\mathrm{y}$ levels according to SAT antibody titers were 224.25, 102 and $69.3 \mathrm{pg} / \mathrm{ml}$, respectively.

Conclusion: Eradication of human brucellosis depends on the eradication of animal brucellosis. In countries like the Kingdom of Saudi Arabia, where brucellosis is endemic; rapid, sensitive and highly specific diagnostic methods are required to make early diagnosis and prevent resistance as there is an overlap in therapy.
\end{abstract}

\section{Introduction}

Brucellosis is a major zoonotic disease that poses a serious public health and economic problem worldwide (Corbel, 1997). The heaviest disease burden lies in countries of the Mediterranean basin and Arabian area. The disease also remains endemic in many countries, particularly in India, Mexico, and South and Central America; however the disease 
incidence and prevalence rates vary widely among nations(Khan et al., 2001). It is estimated that the annual incidence of brucellosis in Saudi Arabia is 21.4/100,000 population (Pappas et al., 2006). The disease is caused by small Gram-negative bacteria belonging to the genus Brucella. It is non-motile, non-encapsulatedcocco-bacilli, which functions as facultative intracellular parasite. There are a few different species of Brucella, each with slightly different host specificity (Meyer, 1990). B. melitensis that is found primarily in goats, sheep and camels and B. abortus that is found primarily in cattle are the principal cause of human brucellosis (Plommet \& Verger, 1996), however B. Melitensisis, the most invasive, produces the most severe disease (Al-Eissa, 1999). The disease is transmitted from animals to humans by direct contact with infected animals, consumption of their infected dairy products, or inhalation of aerosols (Kurdoglu et al., 2010). Other than the possibility of transmission through blood transfusion and organ or bone marrow transplantation, brucellosis is not readily transmitted between human beings (Khan et al., 2001). Brucellosis may be seen in any age group, but it still involves young and middle aged adults more frequently with predominance among males.

The majority of brucellosis cases were attributed to direct contact with animals or their products (Hizel et al., 2007). Although it is thought that brucellosis causes fewer spontaneous abortion in humans than it does in animals due to the lack of erythritol, a preferential medium and growth factor for Brucella, in the human placenta and the presence of anti-Brucella activity in human amniotic fluid, there is some evidence that it may cause a higher rate of complications, such as abortion, preterm labor, and intrauterine fetal demise, more frequently than do other bacterial infections (Hizel et al., 2007). In humans, brucellosis behaves as a systemic infection with a very heterogeneous clinical spectrum. The disease usually presents as fever with no apparent focus, although there are focal forms in $20-40 \%$ of cases. As the clinical picture of human brucellosis is fairly non-specific, a definitive diagnosis requires isolation of the causative organism or the demonstration of high levels of specific antibodies, or seroconversion (Ruiz-Mesa et al., 2005).

During the first week of infection, IgM antibodies against lipopolysaccharide antigens appear in the serum, followed by IgG antibodies as early as the second week. Both antibody isotypes peak during the fourth week, and the use of antibiotics was associated with a decline of both IgM and IgG class antibodies. The diagnosis of brucellosis is based on a detailed history obtained from the patients and the isolation of Brucella spp. from blood cultures are accepted as the standard method. The definitive diagnosis of brucellosis requires isolation of the bacterium from blood, bone marrow or tissue samples. Although the sensitivity of blood culture method varies depending on the individual laboratory practices, quantity of bacteria in blood and the methods used, it changes between 15-70 percent. Bone marrow culture is considered as the gold standard for the diagnosis of brucellosis, since the relatively high concentration of Brucella in reticuloendothelial system enables the detection of the organism. The standard tube agglutination test (SAT) is the most widely used serologic test for the confirmation of human brucellosis. Otherwise, enzyme immunoassays (ELISA) which measure specific $\operatorname{IgM}, \operatorname{IgG}$ and $\operatorname{IgA}$ antibodies, allow for a better interpretation of the clinical situation and overcome the false negativities/positivities which may arise in SAT(Alişka, 2008).The whole-blood interferon-gamma (IFN- $\gamma$ ) assay is a quantitative in vitro assay for a

Copyright (C 2020, Journal of Scientific Research in Medical and Biological Sciences (JSRMBS), Under 
direct read-out of Ag-specific cell-mediated immune (CMI) responses to infectious diseases. The IFN- $\gamma$ assay is robust in severe intracellular infections like Brucella (Riber et al., 2011). For all the above reasons and as human brucellosis has a serious medical impact in Saudi Arabia, the study had been conducted to estimate the prevalence of brucellosis in a Saudi hospital in Al-Madinah Al-Munawarah, determine the most prevalent species of Brucella (Brucellamelitensis, Brucellaabortus), compare the culture and serological methods in diagnosis of those patients with signs and symptoms of brucellosis, and to evaluate levels of sIL-2R and/or IFN- $\gamma$ production during infection with species of Brucella and to detect (if possible) their possibility to be used as markers of treatment efficacy in individuals suffering from brucellosis.

The Kingdom of Saudi Arabia imports millions of sheep and goats each year for the Pilgrimage season. Thus, the eradication of human brucellosis depends on the eradication of animal brucellosis, and the formation of a national program for controlling brucellosis. Prevention of brucellosis can be best achieved by minimizing human contact with infected animals or their products. Hand washing, eye protection, protective clothing, tool/surface disinfection, infected animal slaughter and destruction are some of the more important measures to be taken in farms and other premises. Raw milk and meat consumption should be avoided to prevent infection of the general population (Corbel, 1997).In addition to that, in countries like the Kingdom of Saudi Arabia, where brucellosis is endemic; rapid, sensitive and highly specific diagnostic methods are required to make early diagnosis and prevent resistance as there is an overlap in therapy (Al-Eissa, 1999).

\section{Methodology and Procedures}

\section{Patients}

This study was conducted on a total of 65 patients (42 Male \& 23 Female) suspected of having brucellosis. All the patients were admitted to Prince Sultan Armed Forces Hospital at Al-Madinah Al-Munawrah during the period of November 2015 to June 2016. This study included 18 control subjects (10 Male \& 8 Female) with apparently no evidence of infection with brucellosis (based on absence of brucellosis symptoms currently and no previous history of brucellosis) as negative controls. $5 \mathrm{ml}$ of blood was obtained from patients and controls. The collected serum was stored at $-20^{\circ} \mathrm{C}$ for further tests.

\section{Determination of Brucella Species by Febrile Antigen Kit}

All sera of patients and controls were tested for Brucella antibody (AB) using febrile antigen kit from Plasmatec Laboratory products, UK. Stained antigen suspensions (Brucellaabortus $5 \mathrm{ml}$, Brucellamelitensis $5 \mathrm{ml}$, Positive control $0.5 \mathrm{ml}$ and Negative control $0.5 \mathrm{ml}$ ) are for the identification and quantitative determination of specific antibodies in human sera following infection with certain Brucella pathogens. Febrile antigens were suitable for slide agglutination test against human sera for detection of these agglutinins. Stained antigen suspension were killed bacteria, stained to enhance the reading of agglutination tests. If sufficient homologous antibodies were present, they would cause the suspension to visibly agglutinate. 


\section{Rapid Slid Titration}

It was performed according to the manufacturer's directions. $0.08 \mathrm{ml}, 0.04 \mathrm{ml}, 0.02 \mathrm{ml}$, $0.01 \mathrm{ml}$ and $0.005 \mathrm{ml}$ of undiluted serum were dispensed onto a row of $3 \mathrm{~cm}$ diameter circles by a micropipette. If Agglutination reactions are observed, the titer was calculated according to the following approximate values: $0.08 \mathrm{ml}=1: 20,0.04 \mathrm{ml}=1: 40,0.02 \mathrm{ml}=1: 80,0.01 \mathrm{ml}$ $=1: 160,0.005 \mathrm{ml}=1: 320$

\section{Detection of Brucella IgM / IgG by Novagnost ELISA Kit}

All sera of patients and controls were tested for Brucella $\operatorname{IgM} \mathrm{AB}$ andBrucella $\operatorname{IgG}$ $\mathrm{AB}$ using novagnost kit from Nova Tec, Germany.

Photo (1):Detection of anti- Brucella IgG antibodies in examined patients using ELISA

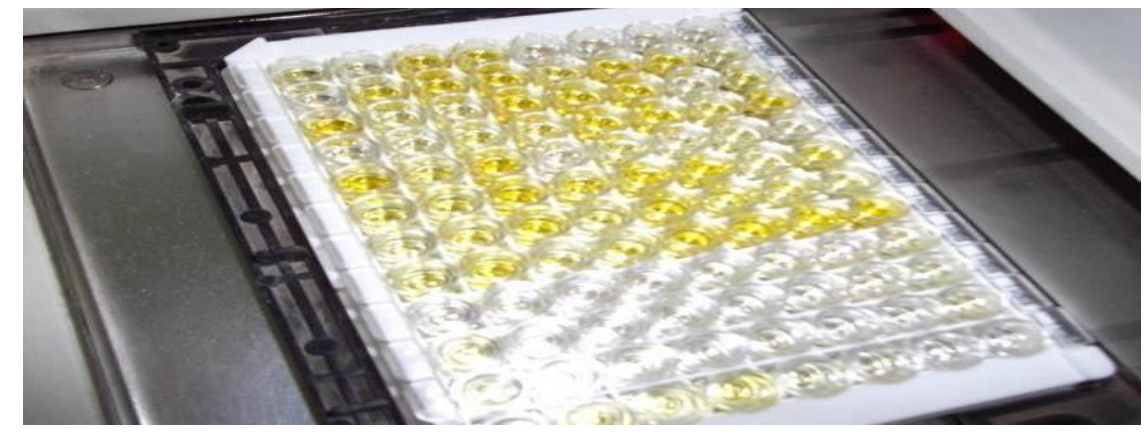

Photo (2):Detection of anti- Brucella IgM antibodies in examined patients using ELISA

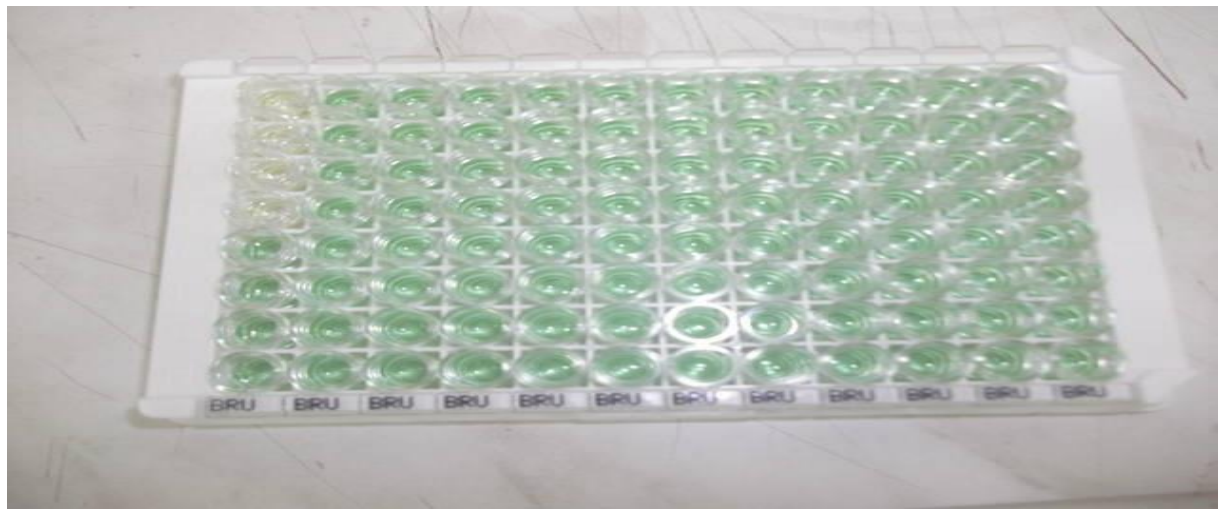

\section{Immunological Assay Human IFN- $\gamma$ :}

The kit used for the quantitation of IFN- was provided by Quantikine (R \& D systems, Inc., Minneapolis, USA). This assay employs the quantitative sandwich enzyme immunoassay technique. It was performed manually according to the manufacturer's directions as shown in table (1). 


\begin{tabular}{lll}
\hline Standard conc. & Diluent & Standard added \\
$1000 \mathrm{pg} / \mathrm{ml}$ & $500 \mu \mathrm{l}$ & $500 \mu \mathrm{l}$ of $2000 \mathrm{pg} / \mathrm{ml}$ stock \\
$500 \mathrm{pg} / \mathrm{ml}$ & $500 \mu \mathrm{l}$ & $500 \mu \mathrm{l}$ of $1000 \mathrm{pg} / \mathrm{ml}$ standard \\
$250 \mathrm{pg} / \mathrm{ml}$ & $500 \mu \mathrm{l}$ & $500 \mu \mathrm{l}$ of $500 \mathrm{pg} / \mathrm{ml}$ standard \\
$125 \mathrm{pg} / \mathrm{ml}$ & $500 \mu \mathrm{l}$ & $500 \mu \mathrm{l}$ of $250 \mathrm{pg} / \mathrm{ml} \mathrm{standard}$ \\
$62.5 \mathrm{pg} / \mathrm{ml}$ & $500 \mu \mathrm{l}$ & $500 \mu \mathrm{l}$ of $125 \mathrm{pg} / \mathrm{ml}$ standard \\
$31.2 \mathrm{pg} / \mathrm{ml}$ & $500 \mu 1$ & $500 \mu \mathrm{l}$ of $62.5 \mathrm{pg} / \mathrm{ml}$ standard \\
$15.6 \mathrm{pg} / \mathrm{ml}$ & $500 \mu \mathrm{l}$ & $500 \mu \mathrm{l}$ of $31.2 \mathrm{pg} / \mathrm{ml}$ standard \\
\hline
\end{tabular}

Figure (1):Standardcurve of IFN- $\gamma$ concentration (Quantikine, $R \& D$ systems, Inc., Minneapolis, USA.

\section{Statistical Analysis}

All data were analyzed using GRAPHPAD PRISM software (GraphPad, San Diego, CA). Data were analyzed using ANOVA (multiple groups), and multiple comparisons between the groups were performed using Newman-Keuls method after ANOVA. P $<0.05$ was considered as statistically significant for all experiments. All values were presented as the mean \pm SD.

\section{Results and Discussion}

\section{Effect of Gender on Brucellosis:}

As shown in figure (2) the slide agglutination test revealed that 60 patients were brucellosis positive with a total incidence of $92.3 \%$. Out of 42 male patients, 40 brucellosis cases were recovered with an incidence of $95.2 \%$. On the other hand, 20 brucellosis cases were identified from 23 female patients with an incidence of $87 \%$. It was of interest to note that male: female ratio in this study was 2:1" P-value 0.231 "

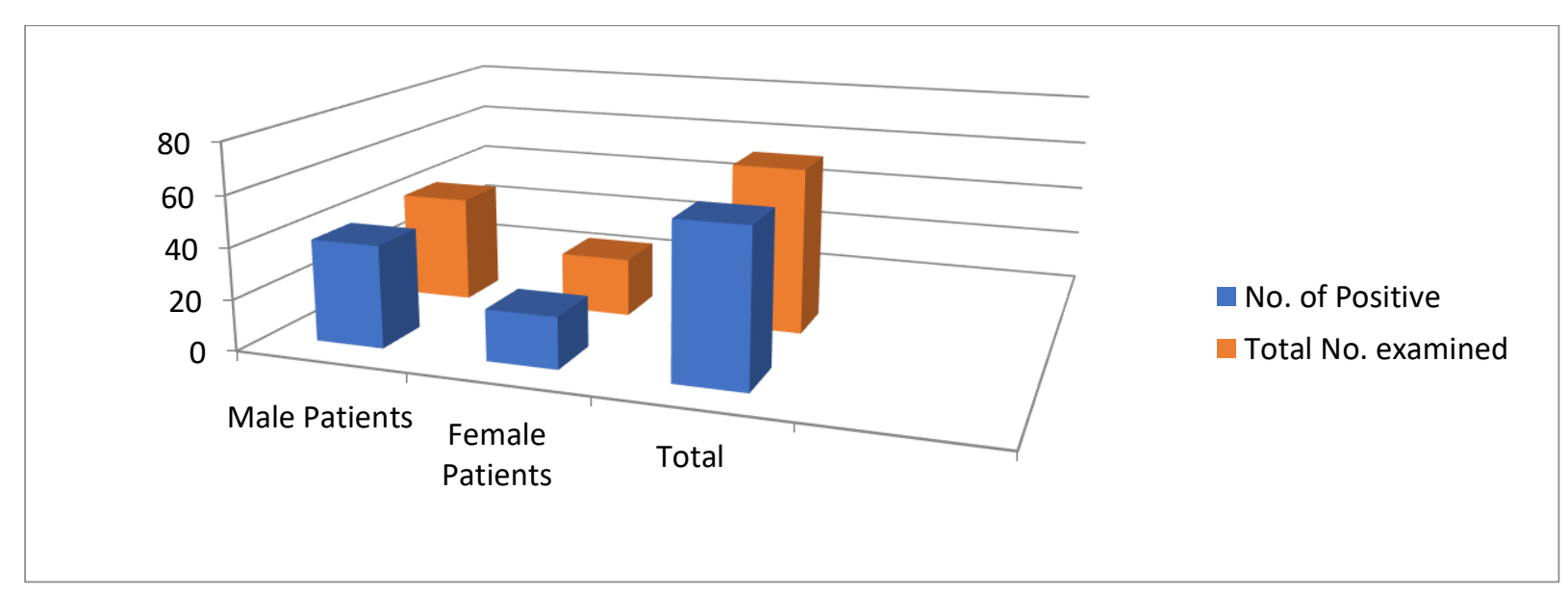

Figure (2): Distribution of brucellosis cases by gender of examined patients 


\section{Effect of Age on Brucellosis}

The results recorded in table (2) show that out of 65 examined patients, 3 patients were belonging to age (10-20 years old), 9 patients were belonging to age (20-30 years old), 14 patients were belonging to age (30-40 years old), 25 patients were belonging to age (40-50 years old) and 14 patients were belonging to age (50-60 years old). Based on results of slide agglutination test, the incidence of brucellosis among these patients groups were $100 \%, 89 \%$, $93 \%, 88 \%$ and $100 \%$, respectively.

Table (2): Distribution of brucellosis cases by age of patients

\begin{tabular}{lllll}
\hline Age & $\begin{array}{l}\text { Total No. of } \\
\text { examined patients }\end{array}$ & $\begin{array}{l}\text { No. }(\%) \\
\text { Of Positive }\end{array}$ & Mean \pm S.D & P-value \\
$10-20$ & 3 & $\begin{array}{l}3 \\
(100 \%)\end{array}$ & $19.3 \pm 0.577$ & \\
$20-30$ & 9 & $\begin{array}{l}(89 \%) \\
13\end{array}$ & $27.4 \pm 2.26$ & \\
$30-40$ & 14 & $\begin{array}{l}(93 \%) \\
22\end{array}$ & $36.8 \pm 2.35$ & 0.695 \\
$40-50$ & 25 & $\begin{array}{l}(88 \%) \\
14\end{array}$ & $44.9 \pm 3.05$ & \\
$50-60$ & 14 & $(100 \%)$ & $56.9 \pm 3$ & \\
Total & 65 & $\begin{array}{l}60 \\
(92.3 \%)\end{array}$ & $42.3 \pm 11.11$ & \\
& & & & \\
\hline
\end{tabular}

Source: Authors

\section{Distribution of Brucellosis Cases by Season}

From Figure (3), it is noticed that the most of brucellosis patients were recovered during the period from January to June with an incidence of $100 \%$ for all months except March was $83 \%$. On the other hand, the examined patients during November and December were negative for brucellosis using slid agglutination test " $P$-value 0.000 ".

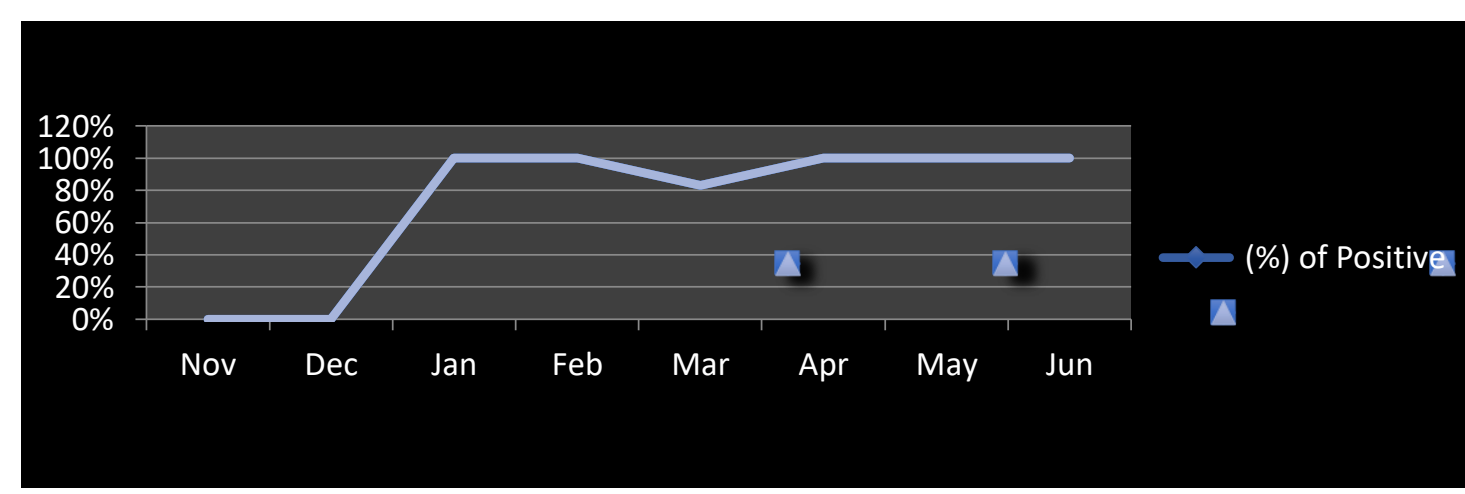

Figure (3): Distribution of brucellosis cases by season 


\section{Effect of Risk Factors on Brucellosis}

It can be concluded from figure (4) that there were different risk factors for brucellosis. Consumption of milk products, heating raw milk and milking animals were the most risk with an incidence of $100 \%$ followed by drinking raw milk with an incidence of $95 \%$. Mean while, cutting raw meat and animal contact were the less risk with an incidence of $80 \%$ and $67 \%$, respectively "P-value 0.142 ".

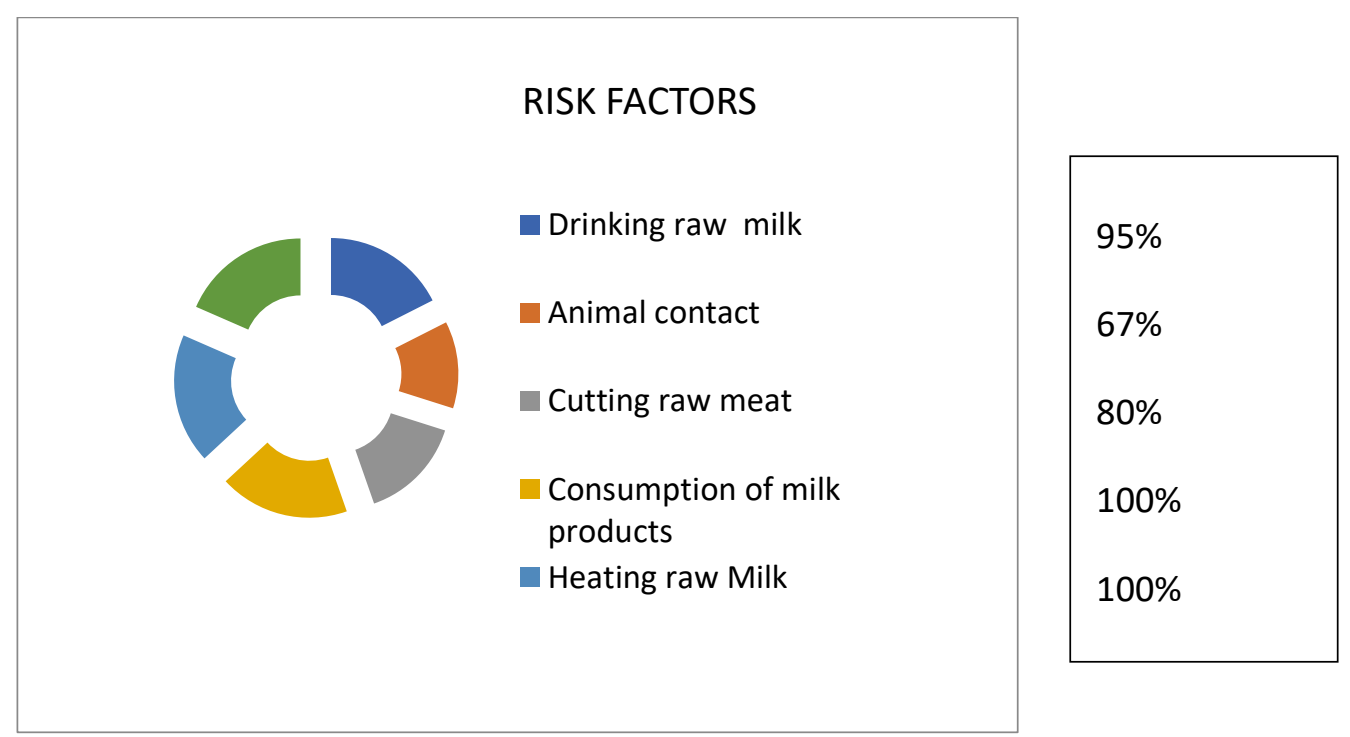

Figure (4): Distribution of brucellosis cases by risk factor

\section{Titers of Anti-Brucella Antibodies in Brucellosis Patients}

Anti-Brucella antibodies of brucellosis cases were evaluated also using rapid slid agglutination test. From data available in table (3), it is evident that anti-Brucella antibodies titers reach to 80 in fourteen cases, 160 in thirty four cases and 320 in twelve cases.

Table (3): No. (\%) Of Brucellosis Patients for Each SAT Antibody Titers

$\begin{array}{ccc}\text { SAT anti-Brucella antibody titers } & \text { No. }(\%) \text { of Positive cases } & P \text {-value } \\ 1 / 80 & 14(22 \%) & \\ 1 / 160 & 34(52 \%) & \\ 1 / 320 & 12(18.5 \%) & 0.000 \\ 1 / 640 & 0(0 \%) & \\ \text { Total } & 60(92.3 \%) & \end{array}$

Source: Authors

\section{Results Of Brucella Species Detection}

Using slide latex agglutination test are presented in figure (5). They illustrated that the most prevalent species among examined patients was B. melitensis $(86 \%)$ with $P$-value 0.551 . On the other hand, B. abortus was detected from only $(6 \%)$ of examined cases with $P$-value 0.000 . 


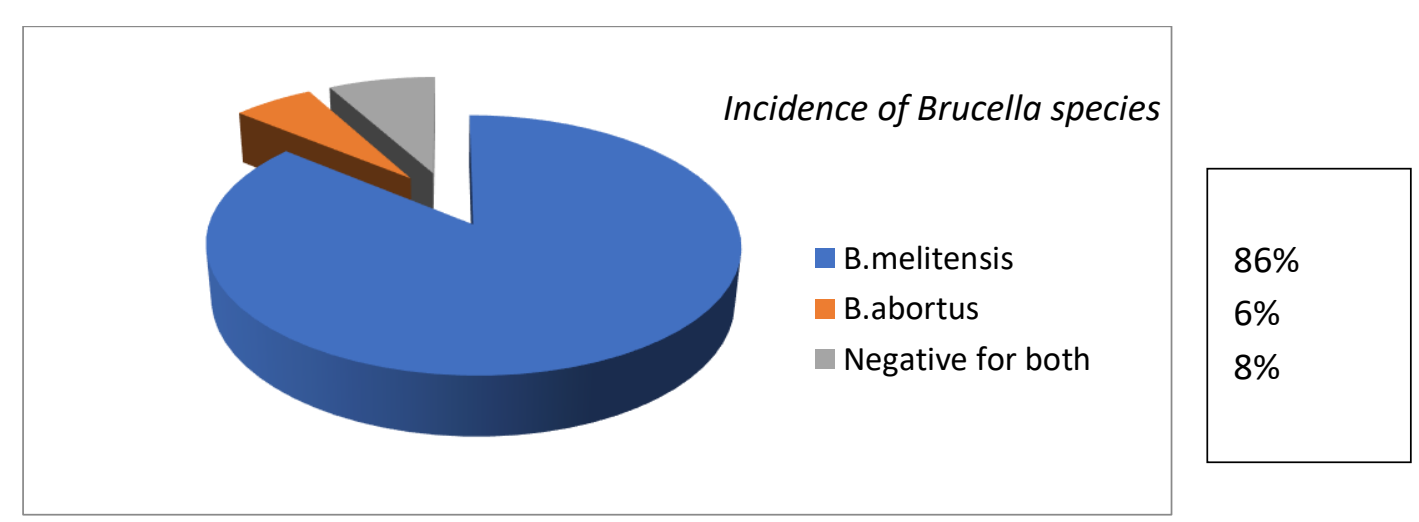

Figure (5): Incidence of Brucella species among examined patients

\section{Results of Detection of Anti-Brucella IgM Antibodies and anti- Brucella IgG Antibodies in Examined Eatients Using (ELISA)}

Estimation of Brucella specific $\operatorname{IgG}$ and $\operatorname{IgM}$ antibody levels in the sera of examined patients as shown in table $(4 \& 5)$ and photo $(1 \& 2)$ revealed that the sera of $38(63 \%)$ brucellosis patients were containing anti- Brucella Ig G antibodies and 22 (37\%) were negative. However, the sera of $4(80 \%)$ patients free from brucellosis were containing antiBrucella $\operatorname{IgG}$ antibodies and only one (20\%) was negative. On the other hand, the sera of 50 $(83 \%)$ brucellosis patients were containing anti- Brucella Ig M antibodies and 10 (17\%) of them were negative. However, the sera of $2(40 \%)$ patients free from brucellosis were containing anti- Brucella IgM antibodies and $3(60 \%)$ of them were negative. The data presented in table (6) recorded $34(57 \%)$ patients with brucellosis and only one (20\%) patient free from brucellosis were containing $\operatorname{IgG} / \mathrm{IgM}$ combined antibodies in their sera. It is of interest to note that $6(10 \%)$ patients with brucellosis were negative for both.

Table (4): Results of detection of anti- Brucella IgG antibodies in examined patients using ELISA comparing with SAT

\begin{tabular}{|c|c|c|c|c|c|}
\hline Patients & $\begin{array}{l}\text { IgG No. (\%) } \\
\text { Positive }\end{array}$ & & Sensitivity & Specificity & $P$-value \\
\hline $\begin{array}{l}\text { Patients with } \\
\text { brucellosis } \\
(60) 2\end{array}$ & $\begin{array}{l}38 \\
(63.3 \%)\end{array}$ & $\begin{array}{l}22 \\
(36.7 \%)\end{array}$ & $63.3 \%$ & $20 \%$ & 0.454 \\
\hline $\begin{array}{l}\text { Patients } \\
\text { free from } \\
\text { brucellosis } \\
\text { (5) }\end{array}$ & $\begin{array}{l}4 \\
(80 \%)\end{array}$ & $\begin{array}{l}1 \\
(20 \%)\end{array}$ & & & \\
\hline
\end{tabular}

Source: Authors

Copyright (C) 2020, Journal of Scientific Research in Medical and Biological Sciences (JSRMBS), Under 
Table (5): Results of detection of anti-Brucella IgM antibodies in examined patients using ELISA comparing to SAT

\begin{tabular}{|c|c|c|c|c|c|}
\hline \multirow[t]{2}{*}{ Patients } & \multicolumn{2}{|c|}{$\begin{array}{l}\text { IgG/M Combined } \\
\text { No. }(\%)\end{array}$} & \multirow[t]{2}{*}{ Sensitivity } & \multirow[t]{2}{*}{ Specificity } & \multirow[t]{2}{*}{$P$-value } \\
\hline & 3 & Negative & & & \\
\hline $\begin{array}{l}\text { Patients with } \\
\text { Brucellosis } \\
\text { having IgG/M } \\
\text { combined positive } \\
\text { or negative (40) }\end{array}$ & $\begin{array}{l}34 \\
(85 \%)\end{array}$ & $\begin{array}{l}6 \\
(15 \%)\end{array}$ & $85 \%$ & $0 \%$ & 0.675 \\
\hline $\begin{array}{l}\text { Patients } \\
\text { free from } \\
\text { brucellosis } \\
\text { having IgG/M } \\
\text { combined positive } \\
\text { or negative (1) }\end{array}$ & $\begin{array}{l}1 \\
(100 \%)\end{array}$ & $\begin{array}{l}0 \\
(0 \%)\end{array}$ & & & \\
\hline
\end{tabular}

Source: Authors

Table (6): Results of detection of anti- Brucella IgG/Mcombined Antibodies in examined patients using ELISA comparing to SAT

\begin{tabular}{llllll}
\hline Patients & \multicolumn{2}{l}{ IgM No. (\%) } & Sensitivity & Specificity & P-value \\
& Positive & Negative & & \\
Patients with & & 10 & $83.3 \%$ & $60 \%$ & 0.020 \\
$\begin{array}{l}\text { Brucellosis } \\
(60)\end{array}$ & 50 & $(16.7 \%)$ & & \\
Patients & 2 & 3 & & \\
free from & $(40 \%)$ & $(60 \%)$ & & & \\
brucellosis (5) & & & & \\
\end{tabular}

Source: Results of quantification of human IFN- $\gamma$ :

Interpretation of the readings is based on the tested serum sample was considered as positive if its ELISA absorbance value exceeds the mean value of the negative control samples by more than two standard deviations (Gast et al., 1997). By comparing ELISA absorbance values of IFN- $\gamma$ in sera of examined patients with the calculated cut off value (0.261) we resulted in among patients with brucellosis, 9 cases were having positive levels of IFN- $\gamma$ while all healthy humans were having negative levels of IFN- $\gamma$ (table 7) . 
Table (7): Evaluation of IFN- $\gamma$ levels of examined patients based on cut off value

\begin{tabular}{ccccc}
\hline IFN- $\gamma$ levels & No. (\%) of patients & Range & Mean \pm S.D & P-value \\
$\begin{array}{c}\text { Positive IFN- } \gamma \\
\text { levels }\end{array}$ & $9(14 \%)$ & 0.21 & $0.345 \pm 0.08$ & \\
$\begin{array}{c}\text { Negative IFN- } \gamma \\
\text { Levels }\end{array}$ & $56(86 \%)$ & 0.26 & $0.134 \pm 0.04$ & 0.000 \\
Total & 65 & 0.48 & $0.164 \pm 0.09$ & \\
\hline
\end{tabular}

Source: Authors

\section{Sero-Prevalence of Brucellosis in Humans}

Relationship between the results of SAT and ELISA (IgM, IgG and IFN- $\gamma$ ) in detection of anti-Brucellaantibodies: Results of SAT as well as ELISA (IgG, IgM and IFN- $\gamma$ ) were recorded and tabulated in table (8). 95\%, 83\%, 71\% and $12 \%$ respectively were brucellosis positive males based on these tests. In addition to $87 \%, 74 \%, 52 \%$ and $17 \%$ respectively were brucellosis positive females based on these tests (figure 6).

Table (8): Relationship between the results of SAT and ELISA (IgM, IgG and IFN- $\gamma$ ) in detection of anti-Brucella antibodies (the gold standard method for detection of brucellosis id is SAT).

\begin{tabular}{|c|c|c|c|c|c|c|c|c|c|}
\hline \multirow[t]{3}{*}{ Gender } & \multirow{3}{*}{$\begin{array}{c}\text { No. of examined } \\
\text { patients }\end{array}$} & \multirow{2}{*}{\multicolumn{2}{|c|}{$S A T$}} & \multicolumn{4}{|c|}{ ELISA } & \multicolumn{2}{|c|}{$I F N-\gamma$} \\
\hline & & & & & $M$ & & $g G$ & & \\
\hline & & $+v e$ & $-v e$ & $+v e$ & $-v e$ & $+v e$ & $-v e$ & $+v e$ & $-v e$ \\
\hline Male & 42 & $\begin{array}{l}40 \\
(95 \%)\end{array}$ & $\begin{array}{l}2 \\
(5 \%)\end{array}$ & $\begin{array}{l}35 \\
(83 \%)\end{array}$ & $\begin{array}{l}7 \\
(17 \%)\end{array}$ & $\begin{array}{l}30 \\
(71 \%)\end{array}$ & $\begin{array}{l}12 \\
(29 \%)\end{array}$ & $\begin{array}{l}5 \\
(12 \%)\end{array}$ & $\begin{array}{l}37 \\
(88 \%)\end{array}$ \\
\hline Female & 23 & $\begin{array}{l}20 \\
(87 \%)\end{array}$ & $\begin{array}{l}3 \\
(13 \%)\end{array}$ & $\begin{array}{l}17 \\
(74 \%)\end{array}$ & $\begin{array}{l}6 \\
(26 \%)\end{array}$ & $\begin{array}{l}12 \\
(52 \%)\end{array}$ & $\begin{array}{l}11 \\
(48 \%)\end{array}$ & $\begin{array}{l}4 \\
(17 \%)\end{array}$ & $\begin{array}{l}19 \\
(83 \%)\end{array}$ \\
\hline Total & 65 & $\begin{array}{l}60 \\
(92 \%)\end{array}$ & $\begin{array}{l}5 \\
(8 \%)\end{array}$ & $\begin{array}{l}52 \\
(80 \%)\end{array}$ & $\begin{array}{l}13 \\
(20 \%)\end{array}$ & $\begin{array}{l}42 \\
(65 \%)\end{array}$ & $\begin{array}{l}23 \\
(35 \%)\end{array}$ & $\begin{array}{l}9 \\
(14 \%)\end{array}$ & $\begin{array}{l}5 \\
(86 \%)\end{array}$ \\
\hline
\end{tabular}

\section{Source: Authors}

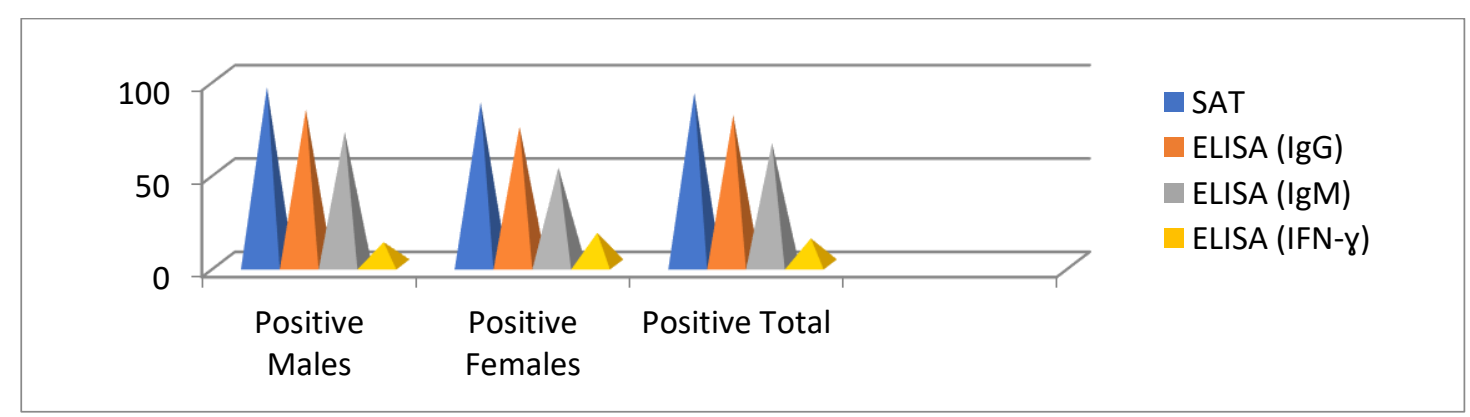

Figure (6): Relationship between the results of SAT and ELISA (IgM, IgG and IFN- $\gamma$ ) in detection of anti-Brucellaantibodies 


\section{Graphical Comparison of SAT with ELISA for Detection of anti-Brucella Antibodies in}

Sera

As indicated, 40 male patients with brucellosis based on SAT were examined using ELISA for the presence of anti-Brucella IgG and IgM antibodies and IFN- $\gamma$ in their sera. The results revealed that $85 \%$ of them were having positive IgM titers, $73 \%$ were having positive IgG titers and $12.5 \%$ were having positive IFN- $\gamma$ levels. However, $80 \%, 45 \%$ and $20 \%$ of female patients with brucellosis were having positive levels of IgM, IgG and IFN- $\gamma$, respectively (table 9 and figure 7). From the same table, it is noticed that B. abortus was detected in three male patients and one female patient with brucellosis. The rest of brucellosis patients were infected with $B$. melitensis. The sensitivity, specificity, negative predictive values and positive predictive values of ELISA tests used in this study are shown in table (10).

Table (9): Distribution of Brucella antibody findings among 65 patients tested by different methods

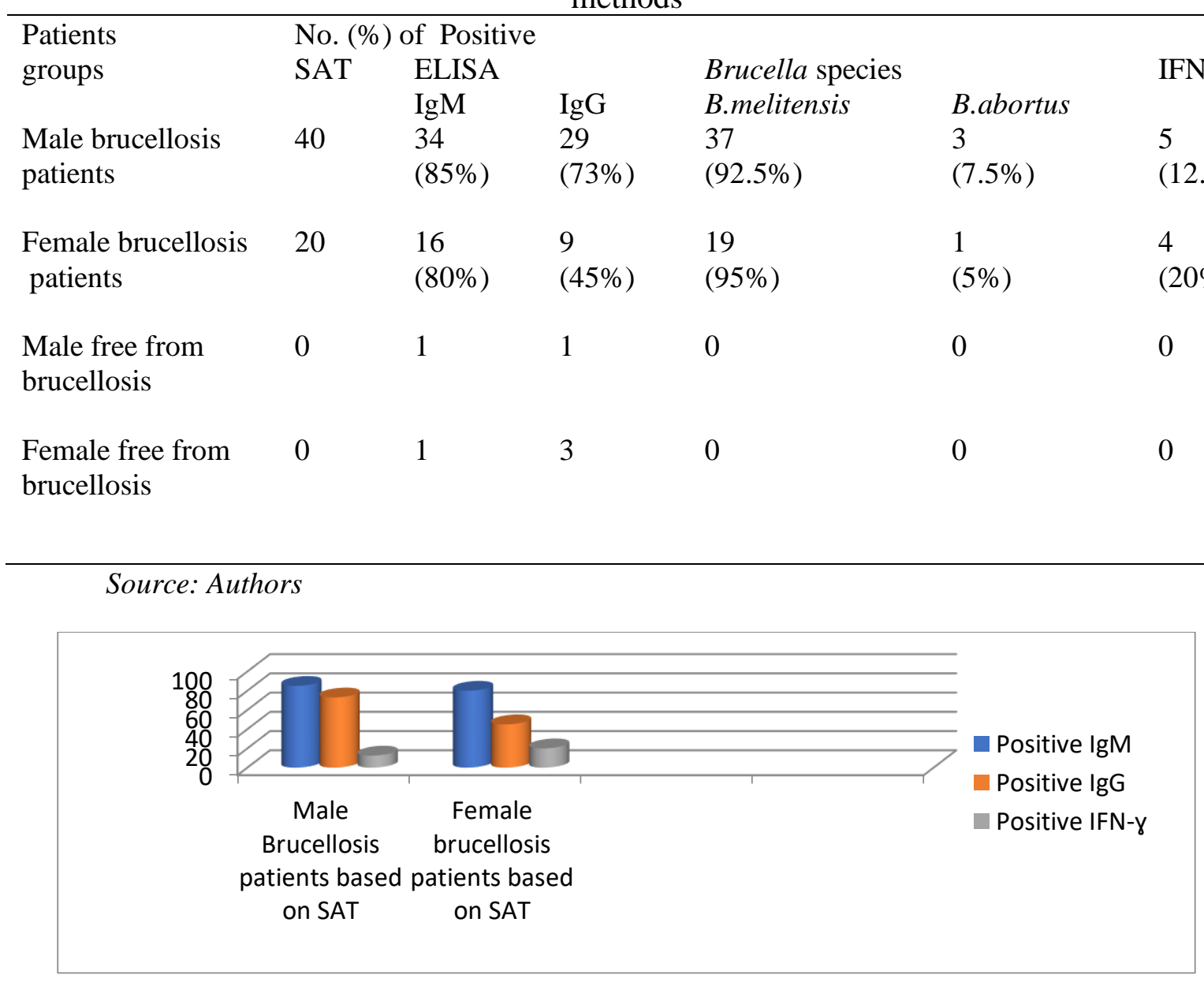

Figure (7): Distribution of Brucella antibody findings among 65 patients tested by different methods 
Table (10): Sensitivity, specificity, negative predictive values and positive predictive values of ELISA used in this study comparing to SAT

\begin{tabular}{ccccc}
\hline ELISA & Sensitivity & Specificity & $P P V^{*}$ & $N P V^{* *}$ \\
& & & & \\
IgG & $63.3 \%$ & $20 \%$ & $90.5 \%$ & $4.4 \%$ \\
IgM & $83.3 \%$ & $60 \%$ & $96.2 \%$ & $23.1 \%$ \\
IFN- $\gamma$ & $15 \%$ & $100 \%$ & $100 \%$ & $8.9 \%$ \\
\hline
\end{tabular}

Source: Authors

* PPV means positive predictive value

**NPV means negative predictive value

\section{Distribution of Positive Results of ELISA According to SAT Titers}

It can be concluded from table (11) that there were differences in ELISA results between $1 / 80,1 / 160$ and 1/320 antibody titer groups. The highest (\%) of patients having positive $\operatorname{IgG}$ and $\operatorname{IgM}$ levels in their sera were in $1 / 160$ antibody titer group. It was also noticed that all positive IFN- $\gamma$ levels were belonging to $1 / 80$ antibody titer group. The mean IFN- $\gamma$ levels according to SAT antibody titers were 224.25, 102 and $69.3 \mathrm{pg} / \mathrm{ml}$, respectively (table 12).

Table (11): Distribution of positive results of ELISA according to SAT titers

\begin{tabular}{|c|c|c|c|c|}
\hline \multirow[b]{2}{*}{ ELISA } & \multicolumn{4}{|c|}{ No. (\%) of Positive for each SAT titer } \\
\hline & $1 / 80$ & $1 / 160$ & $1 / 320$ & Total \\
\hline$I F N-\gamma$ & $9(64 \%)$ & $0(0 \%)$ & $0(0 \%)$ & $9(15 \%)$ \\
\hline $\operatorname{Ig} M$ & $12(86 \%)$ & $30(88 \%)$ & $8(67 \%)$ & $50(83 \%)$ \\
\hline $\operatorname{Ig} G$ & $9(64 \%)$ & $23(68 \%)$ & $6(50 \%)$ & $38(63 \%)$ \\
\hline
\end{tabular}

Source: Authors

Table (12): The mean IFN- $\gamma$ levels $(\mathrm{pg} / \mathrm{ml})$ in relation to the SAT antibody titers

$\begin{array}{lll}\begin{array}{l}\text { Mean ELISA } \\ \begin{array}{l}\text { absorbance value } \\ 0.141\end{array}\end{array} & \begin{array}{l}\text { SAT titers } \\ \text { Control }\end{array} & \begin{array}{l}\text { levels }(\mathrm{pg} / \mathrm{ml}) \\ 105.75\end{array} \\ 0.299 & 80 & 224.25 \\ 0.136 & 160 & 102 \\ 0.092 & 320 & 69.3\end{array}$

Source: Authors

Copyright (C 2020, Journal of Scientific Research in Medical and Biological Sciences (JSRMBS), Under 


\section{Discussion}

In many countries, brucellosis is a nationally notifiable disease and reportable to the local health authority but the underreported and official numbers constitute only a fraction of true incidence of the disease. Thus, the true incidence of human brucellosis is unknown and the estimated burden of the disease varies widely, from $<0.03$ to $>160$ per 100,000 population (Taleski et al., 2002; Pappas et al., 2006) It is estimated that the annual incidence of brucellosis in Saudi Arabia is 21.4/100,000 population (Pappas et al., 2006).

This study was conducted on 65 patients (42 males \& 23 females) suspected of having brucellosis with Male: female ratio (2:1). All patients were presented at Prince Sultan Armed Forces Hospital at Al-Madinah Al-Munawrah, during the period of November 2015 to June 2016. The patients were examined using slide agglutination test for detection of anti-Brucella antibodies in their sera. The results illustrated in figure (2) revealed that 60 patients were brucellosis positive with a total incidence of $92.3 \%$. Out of 42 male patients, 40 brucellosis cases were recovered with an incidence of $95.2 \%$ while 20 brucellosis cases were identified from 23 female patients with an incidence of $87 \%$. On the other hand, the data presented in table (2) pointed out that brucellosis was seen in all age groups however its incidence varied. The incidence reached to $100 \%$ among the age groups (10-20) years old and (50-60) years old. These results generally agree with the previous reports of Mantur et al. (2006) who recorded that human brucellosis affects all age groups and males are affected more commonly than females which may be due to risk of occupational exposure. Also, these results agree with results of Hizel (2007) who concluded that brucellosis may be seen in any age group, but it still involves young and middle aged adults more frequently with predominance among males.

The investigation presented here showed a variation in the incidence of brucellosis from season to another. The most of brucellosis patients were recovered during the period from January to June with an incidence of $100 \%$ for all months except March was $83 \%$. However, the examined patients during November and December were negative for brucellosis using slid agglutination test as shown in figure (3). Elbeltagy (2001) regarded the variation in the incidence of brucellosis among seasons to that a rainy season in an area would result in increased grass growth and thus influx of shepherds and flocks. However, Memish and Mahi (2201) recorded that the highest incidence of brucellosis in Saudi Arabia was seen in spring and summer seasons.

Many researchers discussed the transmission of brucellosis. They confirmed that the disease is transmitted from animals to humans by direct contact with such infected animals, consumption of their infected dairy products, or inhalation of aerosols (Kurdoglu et al., 2010). Other than the possibility of transmission through blood transfusion and organ or bone marrow transplantation, brucellosis is not readily transmitted between human beings (Khan et al., 2001). The occupational source of exposure predisposes the farmers, shepherds, butchers, laboratory workers, veterinarians and slaughterhouse workers to a greater risk of contracting the disease through inhalation of contaminated aerosols, contact with conjunctival mucosa, or entry of the bacteria through cuts and abrasions in the skin as a result of contact with infected animals or their products (Cutler et al., 2005). The non-occupational sources of exposure 
include ingestion of infected meat, unpasteurized milk and milk products (Cutler et al., 2005). In recent years there has been a shift towards food borne brucellosis transmitted by raw animal product consumption in urban populations. For example, consumption of traditional Arabian /African delicacies such as raw liver can cause human infection (Malik, 1997). In this respect, we evaluated the effect of risk factors on brucellosis incidence. It can be concluded from figure (4) that there were different risk factors for brucellosis. Consumption of milk products, heating raw milk and milking animals were the most risk with an incidence of $100 \%$ followed by drinking raw milk with an incidence of $95 \%$. However, cutting raw meat and animal contact were the less risk with an incidence of $80 \%$ and $67 \%$, respectively. These results presented new data than Seimenis et al.(2006) suggested that animal contact still remains the predominant transmission mode in rural and nomadic populations, practicing traditional husbandry. The results of this study agree with the previous report of Al-Eissa et al. (1990) who studied 102 cases of children with proven brucellosis. He found that the main source of infection was the consumption of raw milk in $80 \%$ of the cases. On the other hand, inhalation of particles, accidental inoculation and ingestion or direct contact may be responsible for the potential hazard of Brucella to laboratory personnel (Charissis \& Vassalos, 2009). A number of cases of laboratory acquired infections have been reported ${ }^{\text {[23- }}$ 27]. Laboratory-associated infections represent $2 \%$ of reported cases of brucellosis (Sewell, 1995; Fleming \& Hunt, 2006; Collins, 1988) demonstrating the high risk of acquiring Brucella infection in clinical microbiology laboratories where these highly infective bacteria are handled. Also, Weinstein and Singh (2009) concluded that brucellosis continues to be the most frequently reported laboratory associated bacterial infection worldwide. Therefore, biosafety level (3) precautions are required to isolate Brucella in a laboratory (Charissis \& Vassalos, 2009). Brucella seemed to be of prominent interest as it can be easily transmitted via aerosols to humans. The organism is believed to have a low infective dose in humans of only 10 bacteria and 50 to $80 \%$ of exposed persons will develop clinical disease. In this scope, Khan et al. (2001) reported that other than the possibility of transmission through blood transfusion and organ or bone marrow transplantation, brucellosis is not readily transmitted between human beings. Congenital brucellosis has been reported but it is rare. Recently, other routes of transmission have been identified such as infection through breast milk, having an infected household member (Sofian et al., 2008); through sexual transmission and the infection contracted by an obstetrician during the delivery of a transplacentally infected baby (Akçakuş et al., 2005). In the Kingdom of Saudi Arabia, camel's milk may be sold on the main streets and is considered a delicacy. On the premise of increased freshness, the milk is provided frothy and warm from the camel. It is even much easier for campers in the desert to find providers of such kinds of camel or goat milk. In other parts of the Middle East, fresh goat's cheese may be sold in supermarkets. If such cheeses were purchased and consumed without cooking, there would be a good chance of disease transmission (Memish \& Balkhy, 2004).

Saudi Arabia is a vast reservoir of human brucellosis. Regional endemicity varies in Saudi Arabia, partly according to climate factors; a rainy season in an area would result in increased grass growth and thus influx of shepherds and flocks (Elbeltagy, 2001). The increased incidence of brucellosis in this country is also attributed to massive importations of 
uncontrolled slaughter animals and inadequate quarantine procedures (Memish, 2001 ).The absence of health literacy, which could interrupt the direct link between animal and human disease, is also critical(Bilal et al., 1991). Brucellosis in Saudi Arabia is hyper endemic, with more than 8000 cases reported each year to public health authorities. During 1998, brucellosis ranked as the No. 1 reportable communicable disease (22.5\%) in Saudi Arabian National Guard communities (Memish \& Mah, 2001).

The annual cases of brucellosis in Saudi Arabia were 15,933 and 5781 in 1997 and 1998, respectively (Pappas et al., 2005). Few studies described the epidemiology of brucellosis in some parts of Saudi Arabia(Al-Sekait, 1993; Fallatah et al., 2005). The human brucellosis cases increased sharply during the period 1985-1990 from 4.9 to 69.5 per 100,000. The highest rate was recorded in 1988 (796 per 100,000). The infection was reported all over the kingdom, but with marked increase at Al-Jouf; Aser and Qasiem (Memish \& Mah, 2001). In addition to that the incidence of the disease is high in the Central Najed region, around the city of Riyadh, an area where part of the population has a nomadic heritage which perpetuates the ingestion of fresh camel, goat and sheep milk (Al-Eissa, 1999; Hafez, 1986). Many measures to control the disease were implemented as early as 1983 in Saudi Arabia (AlBallaa, 1994). More recently, it is estimated that the annual incidence of brucellosis in Saudi Arabia is 21.4/100,000 population (Pappas et al., 2006). Morbidity in the Saudi population continues to be reported with increasing frequency from various regions of the country, particularly from the rural areas, and human infection is in the range of 1.6\%-2.6\% (Alballa, 1995; Al-Nasser et al., 1991). Khan et al. (2001) reviewed 92 pregnant women who presented with acute brucellosis at a Saudi Arabian hospital. From 1983 to 1995, the cumulative incidence of pregnancy and brucellosis was 1.3 cases per 1000 delivered obstetrical discharges. The incidence of spontaneous abortion in the first and second trimesters was $43 \%$, and the incidence of intrauterine fetal death in the third trimester was $2 \%$. For all the above reasons and as human brucellosis has a serious medical impact in Saudi Arabia, the study was conducted to estimate the prevalence of brucellosis in a Saudi hospital in Al-Madinah AlMunawarah and to determine the most prevalent species of Brucella (Brucellamelitensis or Brucellaabortus).

The diagnosis of brucellosis is based on a detailed history obtained from the patients and the isolation of Brucella spp. from blood cultures are accepted as the standard method. The definitive diagnosis of brucellosis requires isolation of the bacterium from blood, bone marrow or tissue samples. Although the sensitivity of blood culture method varies depending on the individual laboratory practices, quantity of bacteria in blood and the methods used, it changes between 15-70 \% . Bone marrow culture is considered as the gold standard for the diagnosis of brucellosis, since the relatively high concentration of Brucella in reticuloendothelial system enables the detection of the organism. In the present investigation, we tried to make blood cultures for the collected samples but unfortunately the Armed forces hospitals (Prince Sultan Armed Forces Hospital, Al-Madinah \& Military Hospital, Riyadh) policy prevents Brucella culturing because it is highly infectious agent and the lack of biosafety cabinet level (3), which is necessary to do the culturing process. The standard tube agglutination test (SAT) is the most widely used serologic test for the confirmation of human brucellosis(Pabuccuoglu et al., 2011).We used rapid slid agglutination test for titration of 
anti-Brucella antibodies of brucellosis cases. From data available in table (3), it is evident that anti-Brucella antibodies titers reach to 80 in fourteen cases, 160 in thirty four cases and 320 in twelve cases. Corbel (1972) said that the serum agglutination test remains the most popular diagnostic tool for brucellosis. Titers above 1:160 are considered diagnostic in conjunction with a compatible clinical presentation. However, in areas of endemic disease, using a titer of 1:320 as diagnostic may be more specific. On the other side, Acha and Szyfres (2003) reported that serum agglutination test (SAT) referred as the standard Brucella agglutination test is commonly used for diagnoses of acute brucellosis. However, 2-mercaptoethanol and complement fixation tests are used for chronic brucellosis, where active infection continues even though agglutination titers return to low levels.

Results of Brucella species detection using slide latex agglutination test are presented in figure (5). They illustrated that the most prevalent species among examined patients was $B$. melitensis (86\%)while B. abortus was detected from only (6\%) of examined cases. These results agree with the report of Elbeltagy (2001) ${ }^{[15]}$ who studied 137 brucellosis cases occurring in Tabuk Province, Saudi Arabia in 1997. Brucellaagglutination titer of $>$ or $=1 / 80$, or rising titer plus history of typical signs and symptoms were considered evidence of infection. The incidence rate was 34/100,000, mean age $33.8+/-13.9$ years (range: 3-72 years) and male: female ratio 1.8:1. The most common infecting agents were $B$. melitensis, $B$. abortus and B. suis.

Al- Dahkou et al. (2003) added to the previous drawbacks that serum agglutination tests have also a major drawback in that they are not suitable for patient follow-up, since titers can remain high for a prolonged period. However, Araj (1999) found that some of these shortcomings can be overcome by modifications such as the addition of EDTA, 2mercaptoethanol, or antihuman globulin. Inaccurate serological results causing incorrect diagnoses are a continuous problem when testing for infectious disease agents in an outbreed population of animals or in human beings. Because of the genetic diversity of populations, some animals will respond with low antibody levels to exposure to Brucellaspp., resulting in false negative results. Other animals will respond with very high levels of antibody which may cause prozoning in some of the older assay types. High responders may also have elevated antibody levels to naturally occurring antibody caused by exposure to cross-reacting microorganisms. Exposure to cross-reacting microorganisms may also cause elevated antibody levels for various periods of time, some prolonged. Both scenarios will result in a false positive serological reaction, a major diagnostic problem in some areas where such microorganisms are endemic (Nielsen \& Yu, 2010). For all these drawbacks, enzyme immunoassays (EIA) which measure specific IgM, IgG and IgA antibodies, allow for a better interpretation of the clinical situation and overcome the false negativities/positivities which may arise in SAT(Alişkan, 2008).

Almuneef and Memish(2003) concluded that Enzyme-linked immunosorbent assay (ELISA) has been evaluated for many years for their diagnosis performance to detect serum antibody to brucellosis. Indirect ELISA typically uses cytoplasmic proteins as antigens. ELISA measures class M, G, and A immunoglobulins, which allows for a better interpretation of the clinical situation and overcomes some of the shortcomings of the serum agglutination test. In this respect, Rahman (2003) recommended using of ELISA for diagnosis of 
brucellosis that it has several advantages when compared with other tests. Firstly, it has a direct method of identification of specific antibody and therefore, it is not prone to false positive reactions. Secondly, it is more sensitive than other the agglutination test and thus has the potential to detect infected animals. Thirdly, the antibody enzyme conjugate employed is able to detect all classes of antibody. A combine determination of all classes of antibody allows accurate serological diagnosis at any stages of disease. Fourthly, ELISA results provide an epidemiological tool for investigation the infective status of flocks. Also, Patra et al. (2014) concluded that Serological tests are more sensitive as compared to blood culture. ELISA is most sensitive and rapid for the diagnosis of brucellosis. A combination of IgM and IgG ELISA was found to be most efficient for detecting brucellosis, among the techniques evaluated. Therefore, in this study we estimated Brucella specific IgG and IgM antibody levels in the sera of examined patients using ELISA. As shown in table (4 \& 5) the sera of 38 $(63 \%)$ brucellosis patients were containing anti- Brucella Ig G antibodies and 22 (37\%) were negative. However, the sera of $4(80 \%)$ brucellosis free patients were containing antiBrucella Ig G antibodies and only one (20\%) was negative. On the other hand, the sera of 50 (83\%) brucellosis patients were containing anti-Brucella IgM antibodies and $10(17 \%)$ of them were negative. However, the sera of $2(40 \%)$ brucellosis free patients were containing anti- Brucella $\operatorname{Ig~M}$ antibodies and $3(60 \%)$ of them were negative.

The data presented in table (6) recorded $34(57 \%)$ patients with brucellosis and only one $(20 \%)$ brucellosis free patients were containing $\operatorname{IgG} / \mathrm{IgM}$ combined antibodies in their sera. It is of interest to note that $6(10 \%)$ patients with brucellosis were negative for both. The aforementioned results threw more light on the appearance of Brucella specific IgM and IgG antibodies in sera. Mantur et al. (2007) explained that during the first week of infection, IgM antibodies against lipopolysaccharide antigens appear in the serum, followed by IgG antibodies as early as the second week. Both antibody isotypes peak during the fourth week, and the use of was associated with a decline of both IgM and IgG class antibodies. They also recommended thatBrucella specific $\operatorname{IgM}$ and $\operatorname{IgG}$ are still the most common and useful measures for the laboratory diagnosis of brucellosis as they are faster and reduce risk of laboratory acquired infections due to handling Brucella culture.

Recently, the awareness increased to the whole-blood interferon-gamma (IFN- $\gamma$ ) assay as a quantitative in vitro assay for a direct read-out of Ag-specific cell-mediated immune (CMI) responses to infectious diseases. Riber et al.(2011) confirmed that the IFN- $\gamma$ assay is robust in severe intracellular infections like Brucella. For this reason, we evaluated levels of IFN- $\gamma$ in sera of examined patients using ELISA to be used as a marker for brucellosis. Interpretation of the readings is based on the tested serum sample was considered as positive if its ELISA absorbance value exceeds the mean value of the negative control samples by more than two standard deviations(Gast et al., 1997). By comparing ELISA absorbance values of IFN- $\gamma$ in sera of examined patients with the calculated cut off value $(0.261)$ we found that among patients with brucellosis, 9 cases were having positive levels of IFN- $\gamma$ while all brucellosis free patients were having negative levels of IFN- $\gamma$ (table 7). The sensitivity, specificity, negative predictive values and positive predictive values of ELISA tests used in this study are shown in table (10). Finely, we compared between results of the used serological methods in diagnosis of those patients with signs and symptoms of 
brucellosis. Results of SAT as well as ELISA (IgG, IgM and IFN- $\gamma$ ) were recorded and tabulated in table (8). 95\%, 83\%, $71 \%$ and $12 \%$ respectively were brucellosis positive males based on these tests. In addition to $87 \%, 74 \%, 52 \%$ and $17 \%$ respectively were brucellosis positive females based on these tests (figure 6). Also, examining of 40 male patients with brucellosis based on SAT using ELISA for the presence of anti-Brucella IgG and IgM antibodies and IFN- $\gamma$ in their sera resulted in $85 \%$ were having positive IgM titers, $73 \%$ were having positive IgG titers and $12.5 \%$ were having positive IFN- $\gamma$ levels. However, $80 \%, 45 \%$ and $20 \%$ of female patients with brucellosis were having positive levels of $\operatorname{IgM}, \operatorname{IgG}$ and IFN- $\gamma$, respectively (table 9 and figure 7).

In addition to that, it can be concluded from tables (11) that there were differences in ELISA results between 1/80,1/160 and 1/320 antibody titer groups. The highest (\%) of patients having positive $\mathrm{IgG}$ and IgM levels in their sera were in 1/160 antibody titer group. It was also noticed that all positive IFN- $\gamma$ levels were belonging to $1 / 80$ antibody titer group. The mean IFN- $\gamma$ levels ( $\mathrm{pg} / \mathrm{ml}$ ) according to SAT antibody titers were 224.25, 102 and 69.3, respectively (table 12). Therefore, Araj (2010) found that in order to achieve the most reliable diagnosis of human brucellosis, it is recommended that a laboratory use a combination of two agglutination tests, namely SAT and indirect Coombs or SAT and Brucellacapt, or ELISA for $\mathrm{IgG}$ and IgM. This allows the detection of antibodies at different stages of the disease, since in the acute stage any test can be positive whereas in chronic, complicated or focal cases SAT can be negative while Coombs, Brucellacapt and ELISA IgG are positive.

\section{Conclusion and Suggestion}

In conclusion, in countries like the Kingdom of Saudi Arabia, where brucellosis is endemic; rapid, and sensitive, highly specific diagnostic methods are required to make early diagnosis and prevent resistance as there is an overlap in therapy. The gold standard method in this study was SAT.

\section{Conflict of Interest}

No conflict of interest

\section{Funding:}

This research work is funded by Prince Sultan Armed Forces Hospital at Al-Madinah AlMunawrah, Saudi Arabia.

\section{References}

Al-Eissa, Y. A. (1999). Brucellosis in Saudi Arabia: past, present and future. Annals of Saudi Medicine, 19: 403-405.

Al-Eissa, Y. A., Kambal, A. M., Al-Nasser, M. N., Al-Habib, S. A., Alfawaz, I. M., \& Al-Zamil, F. A. (1990). Childhood brucellosis: a study of 102 cases. The Pediatric infectious disease journal, 9(2), 74-79.

Alişkan, H. (2008). The value of culture and serological methods in the diagnosis of human 
brucellosis. Mikrobiyoloji bulteni, 42(1), 185-195.

Al-Sekait, A. M. (1993). Prevalence of brucellosis among abattoir workers in Saudi Arabia. Journal of the Royal Society of Health, 113(5), 230-233.

Alballa, S. R. (1995). Epidemiology of human brucellosis in southern Saudi Arabia. The Journal of tropical medicine and hygiene, 98(3), 185-189.

Al-Nasser, A.,Alaska A., Al-Balla S.(1991).Epidemiology of brucellosis in Saudi Arabia. Ann. Saudi Med. 11: 245.

Al-Ballaa, S. R., Al-Balla, S. R., Al-Aska, A., Kambal, A., \& Al-Hedaithy, M. A. (1994). Seasonal variation of culture positive brucellosis at a major teaching hospital. Annals of Saudi medicine, 14(1), 12-15.

Alişkan, H. (2008). The value of culture and serological methods in the diagnosis of human brucellosis. Mikrobiyoloji bulteni, 42(1), 185-195.

Akçakuş, M., Esel, D., Çetin, N., Kisaarslan, A. P., \& Kurtoğlu, S. (2005). Brucella melitensis in blood cultures of two newborns due to exchange transfusion. Turk J Pediatr, 47(3), 272-4.

Ache, N. and Szyfres, S. (2003). B.Brucellosis. In: Zoonoses and Communicable Common to Man and Animals, third ed. 2003; 1.

Almuneef, M., \& Memish, Z. A. (2003). Prevalence of Brucella antibodies after acute brucellosis. Journal of chemotherapy, 15(2), 148-151.

Al-Dahouk, S.,Tommaso, H., \& Nockler, K.(2003). Laboratory-based diagnosis of brucellosis-a review of the literature, Part II: serological tests for brucellosis. Clin. Lab. Sci.; 49: 577 589.

Araj, G. F. (1999). Human brucellosis: a classical infectious disease with persistent diagnostic challenges. Clinical Laboratory Science, 12(4), 207.

(2010). Update on laboratory diagnosis of human brucellosis. International Journal of antimicrobial agents, 36, S12-S17.

Bilal, N. E., Jamjoom, G. A., Bobo, R. A., Aly, O. F., \& El-Nashar, N. M. (1991). A study of the knowledge, attitude and practice (KAP) of a Saudi Arabian community towards the problem of brucellosis. The Journal of the Egyptian Public Health Association, 66(1-2), 227-238.

Corbel, M. J. (1972). Characterisation of antibodies active in the Rose Bengal plate test. Veterinary record, 90(17), 484-485. (1997). Brucellosis: an overview. Emerging infectious diseases, 3(2), 213.

Cutler, S. J., Whatmore, A. M., \& Commander, N. J. (2005). Brucellosis-new aspects of an old disease. Journal of applied microbiology, 98(6), 1270-1281.

Collins, C. H. (1988). Laboratory-acquired infections: history, incidence, causes and prevention. Butterworth \& Co (Publishers) Ltd.

Charissis N, and Vassalos C. (2009). Brucellosis. In: Biological warfare agents. Ekdoseis Korontzis, Athens.

Elbeltagy, K. E. (2001). An epidemiological profile of brucellosis in Tabuk Province, Saudi Arabia. EMHJ-Eastern Mediterranean Health Journal, 7 (4-5), 791-798, 2001.

Fleming, D. O., \& Hunt, D. L. (2006). Biological safety: principles and practices (No. Ed. 4). ASM Press.

Fallatah, S. M., Oduloju, A. J., Al-Dusari, S. N., \& Fakunle, Y. M. (2005). Human brucellosis in Northern Saudi Arabia. Saudi medical journal, 26(10), 1562-1566. 
Gast, R. K., Porter Jr, R. E., \& Holt, P. S. (1997). Applying tests for specific yolk antibodies to predict contamination by Salmonella enteritidis in eggs from experimentally infected laying hens. Avian diseases, 195-202.

Hafez, S. M.( 1986). The impact of uncontrolled animal importation and marketing on the prevalence of brucellosis in Saudi Arabia. Annals of Saudi Medicine. Vol. 6, pp. 15-18.

Hizel, K., Guzel, O., Dizbay, M., Karakus, R., Senol, E., Arman, D., ... \& Ulutan, F. (2007). Age and duration of disease as factors affecting clinical findings and sacroiliitis in brucellosis. Infection, 35(6), 434-437.

Khan, M. Y., Mah, M. W., \& Memish, Z. A. (2001). Brucellosis in pregnant women. Clinical infectious diseases, 32(8), 1172-1177.

Kurdoglu, M., Adali, E., Kurdoglu, Z., Karahocagil, M. K., Kolusari, A., Yildizhan, R., ... \& Akdeniz, H. (2010). Brucellosis in pregnancy: a 6-year clinical analysis. Archives of gynecology and obstetrics, 281(2), 201.

Mantur, B. G., Biradar, M. S., Bidri, R. C., Mulimani, M. S., Veerappa, K., Kariholu, P., ... \& Mangalgi, S. S. (2006). Protean clinical manifestations and diagnostic challenges of human brucellosis in adults: 16 years' experience in an endemic area. Journal of medical microbiology, 55(7), 897-903.

Mantur, B. G., Amarnath, S. K., \& Shinde, R. S. (2007). Review of clinical and laboratory features of human brucellosis. Indian journal of medical microbiology, 25(3), 188.

Memish, Z. A., \& Mah, M. W. (2001). Brucellosis in laboratory workers at a Saudi Arabian hospital. American journal of infection control, 29(1), 48-52.

Memish, Z. (2001). Brucellosis control in Saudi Arabia: prospects and challenges. Journal Chemother. Vol.13, no.11-17-30.

Memish, Z. A., \& Balkhy, H. H. (2004). Brucellosis and international travel. Journal of travel medicine, 11(1), 49-55.

Malik, G. M. (1997). A clinical study of brucellosis in adults in the Asir region of southern Saudi Arabia. The American journal of tropical medicine and hygiene, 56(4), 375-377.

Meyer, M. E. (1990). Current concepts in the taxonomy of the genus Brucella. In Animal brucellosis (pp. 1-17). CRC Press, Inc. Sunderland, Massachusetts.

Pappas, G., Papadimitriou, P., Akritidis, N., Christou, L., \& Tsianos, E. V. (2006). The new global map of human brucellosis. The Lancet infectious diseases, 6(2), 91-99.

Pabuccuoglu, O., Ecemis, T., El, S., Coskun, A., Akcali, S., \& Sanlidag, T. (2011). Evaluation of serological tests for diagnosis of brucellosis. Japanese journal of infectious diseases, 64(4), 272-276.

Nielsen, K., \& Yu, W. L. (2010). Serological diagnosis of brucellosis. Prilozi, 31(1), 65-89.

Rahman, M. S. (2003). Experimental infection and protective immunity of Sprague-Dawley rats with Brucella abortus (Doctoral dissertation, $\mathrm{PhD}$ thesis, College of Veterinary Medicine, Chonbuk National University, Jeonju, South Korea).

Pappas, G., Panagopoulou, P., Christou, L., \& Akritidis, N. (2006). Brucella as a biological weapon. Cellular and molecular life sciences : CMLS, 63(19-20), 2229-2236. https://doi.org/10.1007/s00018-006-6311-4

Pappas, G., Papadimitriou, P., Akritidis, N., Christou, L., \& Tsianos, E. V. (2006). The new global map of human brucellosis. The Lancet infectious diseases, 6(2), 91-99. 
Patra, K. P., Saito, M., Atluri, V. L., Rolán, H. G., Young, B., Kerrinnes, T., ... \& Tsolis, R. M. (2014). A protein-conjugate approach to develop a monoclonal antibody-based antigen detection test for the diagnosis of human brucellosis. PLoS Negl Trop Dis, 8(6), e2926.

Plommet, D., \& Verger, J.(1998). Brucellosis. In: Zoonoses; PalmerSR,Soulsby Land Simpson DIH (Eds.). Oxford University Press,23- 35.

Riber, U., Boesen, H. T., Jakobsen, J. T., Nguyen, L. T., \& Jungersen, G. (2011). Co-incubation with IL-18 potentiates antigen-specific IFN- $\gamma$ response in a whole-blood stimulation assay for measurement of cell-mediated immune responses in pigs experimentally infected with Lawsonia intracellularis. Veterinary immunology and immunopathology, 139(2-4), 257-263.

Ruiz-Mesa, J. D., Sanchez-Gonzalez, J., Reguera, J. M., Martin, L., Lopez-Palmero, S., \& Colmenero, J. D. (2005). Rose Bengal test: diagnostic yield and use for the rapid diagnosis of human brucellosis in emergency departments in endemic areas. Clinical microbiology and infection, 11(3), 221-225.

Seimenis, A., Morelli, D., \& Mantovani, A. (2006). Zoonoses in the Mediterranean region. Annali dell'Istituto superiore di sanita, 42(4), 437-445.

Sewell, D. L. (1995). Laboratory-associated infections and biosafety. Clinical Microbiology Reviews, 8(3), 389-405.

Sofian, M., Aghakhani, A., Velayati, A. A., Banifazl, M., Eslamifar, A., \& Ramezani, A. (2008). Risk factors for human brucellosis in Iran: a case-control study. International journal of infectious diseases, 12(2), 157-161.

Taleski, V., Zerva, L., Kantardjiev, T., Cvetnic, Z., Erski-Biljic, M., Nikolovski, B., ... \& Kirandziski, T. (2002). An overview of the epidemiology and epizootology of brucellosis in selected countries of Central and Southeast Europe. Veterinary microbiology, 90(1-4), 147155.

Weinstein, R. A., \& Singh, K. (2009). Laboratory-acquired infections. Clinical Infectious Diseases, 49(1), 142-147. 